Article

\title{
Socially-Inclusive Development and Value Creation: How a Composting Project in Galicia (Spain) 'Hit the Rocks'
}

\author{
Paul Swagemakers 1,2,*, Maria Dolores Dominguez Garcia ${ }^{2,3}$ and Johannes S. C. Wiskerke 4 (i) \\ 1 Department of Applied Economics, Faculty of Business and Tourism, University of Vigo, \\ Campus Universitario As Lagoas s/n, 32004 Ourense, Spain \\ 2 Governance and Economics research Network (GEN), University of Vigo, Campus Universitario As Lagoas \\ s/n, 32004 Ourense, Spain \\ 3 Department of Applied Economics, Public Economics and Political Economy, Faculty of Social Work, \\ Complutense University of Madrid, Campus de Somosaguas, 28223 Pozuelo de Alarcón, Spain; \\ mariaddo@ucm.es \\ 4 Rural Sociology Group, Department of Social Sciences, Wageningen University, Hollandseweg 1, \\ 6706 KN Wageningen, The Netherlands; han.wiskerke@wur.nl \\ * Correspondence: paul.swagemakers@uvigoes.es; Tel.: +34-986-818644
}

Received: 10 April 2018; Accepted: 11 June 2018; Published: 15 June 2018

\begin{abstract}
This paper introduces the concept of commoning in circular economies, and explores how commons reproduce over time. The starting point is that commoning can have an important role in fostering circular economies and sustainable and socially-inclusive development. By commoning, we refer to local stakeholders working collectively to preserve or restore their natural resource base to generate benefits that are locally shared. Through the analysis of a specific case of a group of commoners' associations in Galicia (Spain), the paper describes and discusses the development, and ultimate unravelling, of an innovative and decentralized waste management project to convert waste biomass from the monte (often-neglected upland green spaces, largely consisting of brush and trees) into compost. In order to make this composting project economically viable the possibility of collecting and processing urban green waste was also explored. While the project's application of the principles of a circular economy had the potential to bring locally-shared economic and ecological benefits, and foster territorial prosperity and resilience, it was ultimately frustrated by questions of scale, administrative and regulatory barriers, competing and conflicting land-use claims and financial cutbacks in the public sector.
\end{abstract}

Keywords: Galicia; circular economy; commoning; decentralized waste management; social innovation

\section{Introduction}

A circular economy is one in which resource efficiency is improved by eliminating avoidable wastes and minimizing demands on (natural) resources, thereby reducing costs. It is built upon creating feedback loops that use waste and residual materials from the end of production processes as 'resources' turning them into valuable inputs [1,2]. Connecting flows and closing cycles offers many opportunities for creating a more regenerative agro-food system and fostering restorative practices and processes [3]. There are several conceptual approaches towards (re)connecting flows and closing cycles within the literature, including 'circular urban metabolism' [4], 'cradle to cradle' [5,6] and 'the circular economy' $[1,2]$. These conceptual approaches embody different but cross-cutting and complementary technological and socio-economic principles and they progressively emphasize the importance of creating value from resources that are currently viewed as waste streams. While there is a wealth of 
technical literature on 'how' to close loops, much less has been written about the social mechanisms involved (i.e., how people can collaborate) and the social benefits of the circular economy.

Murray et al. [2] (p. 25) write that 'of the three pillars of sustainability (social, economic and environmental) it is the former that is least expanded in most of the conceptualizations and applications of the circular economy'. This research gap applies particularly to biological metabolisms/cycles [2], which, for example, includes the ways in which cities' green waste can be used efficiently in a circular economy. Green waste includes the raw materials derived from maintaining parks and pruning roadside trees, bushes and flowerbeds, the waste generated by nursery enterprises and food waste generated by retail chains, the catering industry and households. To our knowledge, the potential for channeling this urban green waste into food production, and its potential social economic and ecological benefits has not received much attention in the literature. In order to contribute to closing the knowledge gap, we will analyze an initiative that is rooted in existing social practices and structures, and holds the potential to feed back biogenic waste materials from cities into food production. The selected case provides an example of a socially-innovative approach to managing green waste that aims to upcycle a combination of forestry waste (also an environmental hazard as a cause of forest fires) and municipal organic waste. This initiative can potentially contribute to creating and strengthening a sustainable and resilient city-region food system [7]. In this way the case study imagines a transformative future [8] in which synergies that are currently lacking between cities, agriculture and forestry are developed in a city-region context $[9,10]$. The model that we discuss is unusual in that, rather than being led by the private or public sector, it follows a third governance model for closing loops, namely that of 'commoning': 'the acts of mutual support, conflict, negotiation, communication and experimentation that are needed to create systems to manage shared resources' [11] (p. 2). Commoning thus refers to the social practices of collaborative decision-making and collective action by local stakeholders, who are preserving or restoring the natural resource base in order to endogenously generate benefits that are locally shared. In this paper we explore commoning in the domain of the circular economy—or more specifically circular agro-food economy—with specific attention to the social sustainability pillar of the circular economy, and identify its limitations when commoning gets confronted with countervailing powers. With this paper we aim to provide insights into how commoning can (potentially) contribute to, and benefit from, locally organized waste management. In this way, we have been able to tease out several dimensions of the social sustainability pillar of the circular economy, which, as mentioned before, are less well studied, discussed and conceptualized in the circular economy literature compared to the economic and environmental dimensions [2].

The paper is structured as follows. In the following section we introduce the conceptual building blocks for our case study, which we describe as a progressive and socially-inclusive conceptual contribution to circular economy thinking. This is followed by a materials and methods section in which we outline the case study and our research approach. We then describe the development and ultimate unraveling of an innovative and decentralized waste management program and analyze the difficulties faced in establishing a unit capable of upcycling biomass, closing material flows and generating jobs and revenue. This is followed by a discussion about the social dimensions of the circular economy that we have inductively derived from this case study: awareness raising, collaborative management and decision-making, the equitable sharing of benefits among local residents, and supportive institutional environments.

We hope that our findings will inspire people to work together in innovative ways and also shed light on the institutional barriers to bringing about positive social, economic and environmental change. In conclusion, we argue that collaborative governance arrangements are needed to spread ideas and innovative practices that meet the challenges of sustainability and help achieve a resource-efficient and participatory society.

\section{Conceptual Building Blocks}

A circular economy preserves and enhances natural resources and optimizes yields by establishing circular flows of energy and materials, which instead of being discarded or wasted at the end of 
a production process, are re-used, thereby becoming valuable inputs [1]. Creating these feedback loops has a technical aspect but more importantly involves an element of social reorganization, bringing together sometimes diverse interests that can extend across multiple networks that 'can potentially realign and spatially embed production/consumption chains capturing local and regional value between rural and urban spaces' [12]. While the durability, repairability and recyclability of products are core aspects of the shift to a circular economy, by-products previously considered as waste hold a potential to be recycled (or upcycled) and to generate value added. In this way 'waste' becomes a valuable asset [13], the value of which emerges in two ways; first, by eliminating the cost of disposing of it and, secondly, by reducing the cost of purchasing inputs or using it to create new products [14-16]. The European Commission's Waste Framework Directive [17] is built around the principles of waste hierarchy $[18,19]$ and has the potential to be an important driver for closing loops. This potential is particularly high in agricultural and forestry production, which rely on natural resources and cycles as their primary inputs. As a result, it is not unreasonable to assume that farmers and other land users will be motivated to seek to increase the coherence and synergies between food production and other functionalities [20,21] by making more use of organic and waste-based fertilizers [22].

\subsection{Commoning as a Social Practice}

There are different, sometimes competing, social-ecological approaches to closing cycles, but all involve a range of actors who work collaboratively to design, develop and implement solutions [23]. Successful waste management requires people to have ideas about, and gain experience with, ways of optimizing the use of local natural resources, which can be of benefit to the actors involved. In community-led initiatives, in which community actors manage their resource base, effective self-governance plays a key role in this process [24,25]. There is an increasing number of studies in the literature in which such initiatives are interpreted as 'commons' [26-28]: 'the shared resources which people manage by negotiating their own rules through social or customary traditions, norms, and practices' [29] (p. 72). Garret Hardin's essay 'the Tragedy of the Commons' [30] highlighted the difficulties of managing of the commons (which was interpreted by many as a clarion call justifying their privatization), but this view was challenged by Elinor Ostrom who saw the commons as 'a dynamic, evolving, social activity: commoning' [11] (p. 6). Linebaugh [31] portrays commoning as an activity, applying the term to people who have a close connection to the commons, differentiating these arrangements from common-pool resources which are open access regimes with no effective system for their management (as in Hardin's model). Building on Elinor Ostrom's work, the principle of commoning refers to (often informal) agreements among people on how to manage shared, inalienable resources, in order to retain benefits within the local community. Establishing such an approach involves including local neighborhood leaders, politicians and technical assistance organizations that make connections, offering the space and providing the resources needed by the community(ies) they serve [32]. Bollier [11] (p. 2) argues that the social practice of commoning includes 'mutual support, conflicts, negotiation, communication and experimentation [to] build a new society [and] greater participatory control over those resources and community life'. He goes on to add (ibid. p. 7) that 'a commons [the shared resource] arises whenever a given community decides that it wishes to manage a resource collectively, with an accent on fair access, use, and long-term sustainability'. A broader interpretation of community engagement in the co-production of a wide range of sustainable, (i.e., environmentally sound and social inclusive) land use can cover activities by 'individuals who are not "in" the same organization' [33] (p. 1073). This implies that such arrangements (formally or informally structured) may not necessarily exist prior to the activity and may, in the latter case, need to be constructed in order for an activity to be developed [34,35].

\subsection{Commoning as Social Innovation}

Building on this argument, commoning can be seen as a social learning process, characterized by distributed cognition (in which actors work together, engaging in activities that are complementary 
even if the actors may hold, possibly, significant difference in perceptions) and double-loop learning (in which the basic aspirations, assumptions and principles of the activity can be modified and result in a shift in understanding) [36]. This implies that not all participants in an initiative (such as a community-level waste management project) need to be aware of the design principles in order for it to be successful, but that all the community members should recognize the benefits of the initiative. The process through which citizens learn how to use resources more sustainably is a form of social innovation, a prominent concept in discussions about making the transition towards sustainability [37]. Building upon Smith et al. [38] and Geels and Schot [39], Bock [37] argues that the social aspect of innovation is essential for the development, diffusion and use of (technical) innovations and that the social and the technical aspects of innovation are 'inseparable'. Bock argues that social innovation is 'characterized by processes of co-design or co-construction and collaboration with society' (ibid p. 58). In so doing Bock emphasizes the importance of social inclusion and the need for changes in politics and governance, that will allow new organizational forms, initiated by local actors, in order to approach challenges from a place-based development perspective rather having them treated as discrete sectoral policy issues (see also [12,37,40-43]). Such changes can be perceived as disruptive to existing practices, since they envisage a system that is configured in a fundamentally different way. Rip and Kemp [44] refer to this as a radical innovation (as opposed to incremental innovation, which involves the gradual adaptation of existing regimes). This leads Bock to contrast social innovation with linear knowledge transfer, characterizing the former as 'a shared, social and circular process' in which different social groups and actors participate, enabling them 'to realize their own development plans, making use of local resources and local knowledge' [37] (p. 60).

Neumeier [45] defines social innovation as involving 'changes of attitudes, behavior or perceptions of a group of people joined in a network of aligned interests that, in relation to the group's horizon of experiences, lead to new and improved ways of collaborative action within the group and beyond' (p. 55). He distinguishes three different stages of social innovation:

(i) an actor or small group of actors developing a plan (deciding to change their behavior);

(ii) following on from which, other actors, hearing about these ideas or plans, become interested, leading to;

(iii) discussion and negotiations among a wider group of actors, through which 'the new form of action [gradually] becomes shaped and solidifies' (p. 58).

Whilst such initiatives may be largely grassroots and spontaneous, there are times at which they need resources 'to incubate'. It is here that local, regional and national institutions and funding bodies can provide support (governing through community) $[37,45,46]$, helping to 'underpin a collectivist asset-based community development model' [46] (p. 9). One of the potential benefits in this approach is to improve and strengthen territorial social capital $[47,48]$ by making use of previously untapped skills, practices, attitudes, values, behaviors and governance mechanisms.

\subsection{Commoning and Closing Cycles}

Effective and socially-inclusive waste and resource management requires adaptive control by group members $[24,25]$ operating in a localized governance structure in order to develop a community-based perspective of societal need that seeks to balance ecological, social and economic benefits [11,49] that will guide the group's investments, in terms of time, money or energy. Waste management can be implemented in different ways: either with a technical bias (in the tradition of ecological modernization) or following a more social-ecological perspective. The technical perspective tends to focus on centralized systems for waste management whereas the social-ecological perspective tends to be a more radical and often disruptive type of innovation $[39,44,50]$ focusing on smaller scales, individual waste streams and waste management within smaller areas, such as individual residences, residential clusters/neighborhoods and small communities [51,52]. Decentralized, social-ecological approaches to the circular economy that promote the reduction, reuse 
and recycling of biological waste can empower participants, both socially and materially, and also bring about beneficial changes in land use. They can bring direct benefits to a wide group of people, and thereby stimulate public interest in sustainable natural resource management [9,53]. In a broader sense, this much-needed transition towards a more regenerative food system needs to be based on the principles of avoiding depleting resources, and seeking cumulative and enduring ecological, social and economic benefits [54].

In this respect, commoning provides a new social ordering principle in which the local, the distinctive, and the historical, matter [11] and open up new avenues for boosting community prosperity and resilience, i.e., the capacity of social, economic and environmental systems to cope with change whilst maintaining and enhancing their essential functions and identity $[55,56]$. This decentralized approach to governance has the potential to create structures in which 'benefits' are differently, and more equally, distributed among the local community. Established interests of municipal and regional governments and of commercial waste collection and energy companies (mostly pursuing a centralized governance approach to resource management) may often be opposed to, and may even seek to frustrate, such approaches. The lack of official public support, which can, and should, connect different governance levels, bridge sectoral barriers, and supply 'room for maneuver' $[40,57,58]$, can be a major obstacle, limiting the potential of 'true' commoning, in which local residents are actively involved in, and benefit from, resource management. Equally, the absence of such supportive mechanisms and the existence of barriers can hamper progress towards a circular economy and sustainable development (as the case study will show).

In the remainder of this paper we describe and analyze a socially and ecologically benign alternative to the conventional approach of organic waste collection and disposal (i.e., landfill or incineration). The 'Mancomunidade Val Miñor' in Galicia (Spain), a grouping of Associations of the Commons that manages upland areas, attempted to initiate a scheme that embodied the practice of 'commoning' in order to create real value for the local community. As we shall see, at the end of the day, the legal and organizational structures that it needed to engage thwarted this effort to achieve 'closed cycles', to manage the forestry commons more sustainably and to upcycle municipal green waste. Yet despite this 'failure', the model they created shows the potential for moving towards restorative practices and processes, and offers opportunities for creating a more sustainable, regenerative, food system. The analysis of this story, of how a group of engaged citizens sought to upcycle resources through closing biological cycles, provides a useful empirical and conceptual contribution to the existing body of literature about the circular economy.

\section{Materials and Methods}

The city of Vigo (with about 300,000 inhabitants) is the largest urban municipality in Galicia (north-western Spain). The city is a mosaic of green and developed areas, with the differences between the urban and rural quite blurred. There are many municipal parks and scattered private plots that are used for vegetable gardening and growing maize, as well as mountain land, locally known as monte. In the city and the wider metropolitan area, part of this monte is owned by public authorities (the state), part is in private hands, and a part is managed as common property (or commons) (but which in fact is collective private property). Our study focuses on these commonly managed areas and the process of commoning in these areas, which we argue provides the basis for a specific form of social innovation, rooted in longstanding social practices and quasi-formal institutional arrangements. In the city region of Vigo, consisting of 14 municipalities and just under half a million inhabitants, attempts are underway to reestablish this principle of commoning in order to create value for the local communities.

This paper describes and analyzes a plan for improving the management of green waste in the city region through establishing and strengthen urban-rural relations, which had the potential to improve natural resource management and to close waste cycles. The case study that we explore, inspired by the conceptual building blocks described in Section 2, is unusual in that it is a decentralized and locally-initiated approach to natural resource management with strong social-ecological foundations, 
which builds upon longstanding institutional arrangements for managing the commons. The initiative stemmed from a desire among the commoners, working through formal organizational structures, to manage their resource base more sustainably, in a way that would materially benefit them $[40,59,60]$ and build upon, and enhance, their engagement with ecological issues [61-63].

\subsection{Communal Management of the Monte}

The monte in Galicia mainly consists of forest and scrubland [64]. In the past, it was a space for farming activities (pastures, cereal production, and providing inputs for increasing soil fertility) and mixed forestry and played a crucial role in supplying the inputs to sustain the resource base of local family farming $[65,66]$. Fertilizer was produced by harvesting Toxo (Ulex europaeus) a nitrogen-rich plant that was highly valued for animal bedding and improving the quality of manure on the small-scale farms. The domestication of the monte compensated for the generally small size of the farms. Apart from providing Toxo, peasants also used the monte to provide themselves with wood for building, making fences etc., heating and gathered other products, including fruits, mushrooms and medicinal herbs [67]. In recent decades, this traditional multifunctional pattern of land-use of the monte has been gradually replaced by monoculture timber plantations, primarily consisting of Pinus pinaster (pine) and Eucalyptus globulus (mostly planted in coastal areas) [68]. More recently, plantations increasingly contain Eucalyptus nitens (a eucalyptus species that is more resistant to cold, and, thus, suitable for planting in the interior, higher, monte areas) [69]. Toxo used to be harvested manually, a practice that has now largely died out. As a result, it now often grows uncontrolled in the monte areas, contributing to the rapid spread of forest fires, especially in monoculture plantations of pine and eucalyptus trees, which are particularly susceptible.

Today, about 670,000 hectares in Galicia (out of a total surface of almost three million hectares) is commonly managed [70]. This Monte Veciñal en Man Comun (the common land) is collectively owned and managed by groups of neighbors or comuneiros: parishioners who are organized in Comunidades de Monte Veciñais en Man Comun (Associations of the Commons). Membership of these associations is strictly limited to people who are resident within the parishes where these organizations operate. These managerial units have the right to make decisions about what is carried out on the common land, decisions that are made in assemblies that must comply with the statutes of the Association of the Commons. This type of property rights and their organizational form are framed by legislation and based on century-long traditions [64,71]. The commons have a number of distinctive characteristics. They are:

- inalienable, implying that owners can never sell their share, and neither government, nor any other authority, can override this ownership;

- imprescriptible, meaning the owners can never lose their rights to the land, except by expropriation for public needs (such as the construction of roads and hospitals, wind parks or mines, etc.);

- unseizable, meaning neither the government nor a bank can confiscate this land in case of debt, and;

- indivisible, meaning the land cannot be divided and must remain a commonly managed unit with the comuneiros collectively deciding on its management.

There are currently about 2800 Associations of the Commons in Galicia, which manage about $25 \%$ of the total territory, much of which is monte area. Although this type of communal structure is widespread in Galicia, Val Miñor's organizational grade and ambitions go beyond the average organizational mode of Associations of the Commons.

\subsection{Upcycling Waste in the City Region of Vigo: The Mancomunidade Val Miñor}

The city region of Vigo contains about 100 of these associations, which manage around 33\% of the monte area (circa 24,400 hectares). The topography of the Vigo region is defined by the 
Serra do Galiñeiro, a 10-kilometer-long granite system that extends through the municipalities of Vigo, Gondomar, Porriño, Mos and Tui. A large part of the Serra is operated by the 'Mancomunidade Val Miñor', a grouping of 12 Associations of the Commons (with a total of 1758 comuneiros) in the municipalities of Baiona, Nigrán, and Gondomar (Figure 1). This group of associations manages about a quarter of the total surface area $(14,390$ hectares) covered by these three municipalities [72].
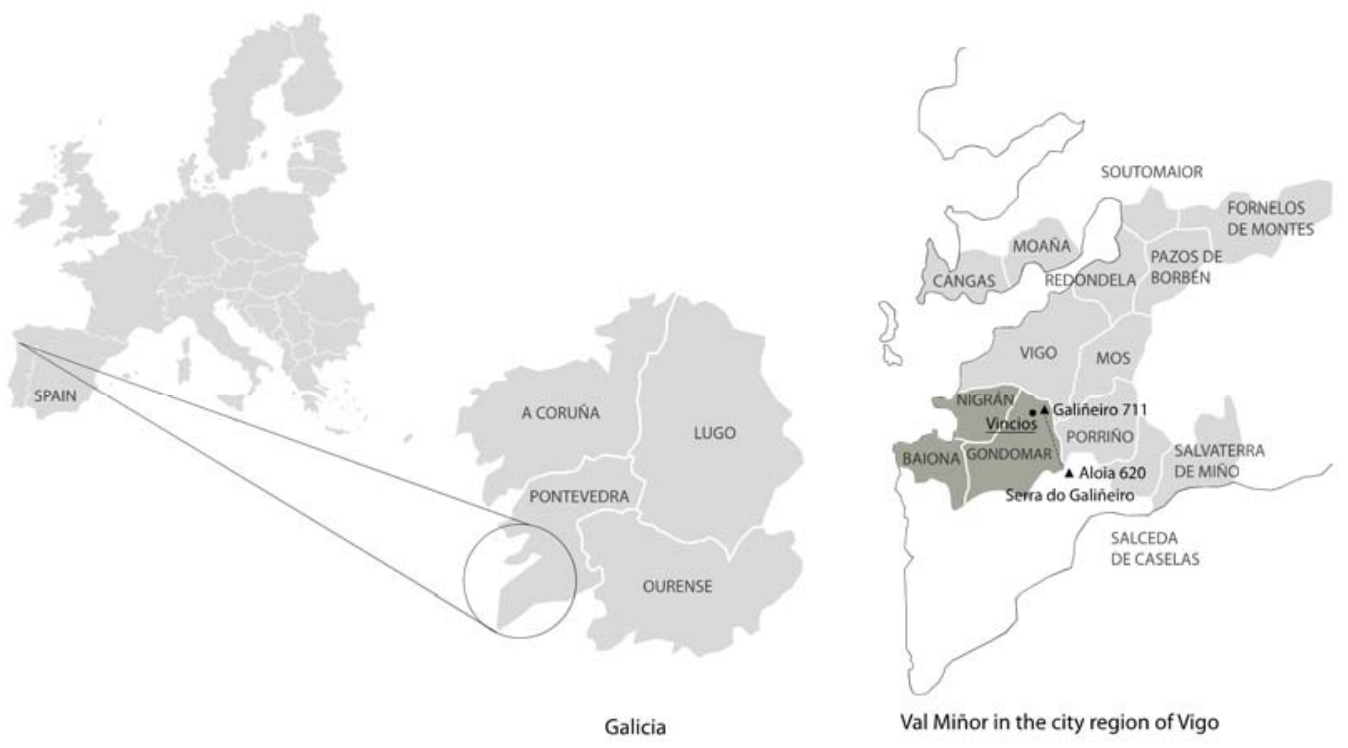

Figure 1. Location of Val Miñor in the city region of Vigo, Galicia (Spain).

In the next section we describe and analyze how the 'Mancomunidade Val Miñor' developed a promising governance mechanism for the sustainable exploitation of the monte area. The case study describes how they sought to benefit from biological resources through reducing, reusing and recycling waste, and establishing a restorative approach to natural resource management. For our analysis, we adopt a story-based approach [73] which is useful in complex and/or changing environments and in a context of long lag times [74]. This involves a well-grounded ethnographic analysis of how the communal management of natural resources works and the difficulties that the local dwellers faced in upcycling waste from the monte and combining it with municipal green waste. We spent several years following the comuneiros' concrete plan [75] for improving land-use in the area, which allowed us to develop an in-depth understanding of the dynamics of commoning and the management of the commons. This allows us to describe how the communeiros stepped up to this challenge and the complex and multi-layered socio-economic, political and socio-historical contexts that led to the emergence and eventual demise of this initiative. But first we provide further details on the applied case study approach.

\subsection{Background and Methodology}

The case study was conducted as part of the European Union (EU)-funded FP7 project entitled 'Towards sustainable modes of urban and peri-urban food provisioning' (SUPURBFOOD: www.supurbfood.eu), which ran from October 2012 to September 2015. However, data collection and analysis continued after SUPURBFOOD ended. SUPURBFOOD was a research and innovation project, carried out in seven European city regions-Vigo being one of them-in which researchers collaborated with small and medium enterprises (SMEs) involved in food production, food distribution and biogenic waste recycling. The aim of the project was to develop, implement and evaluate, through a learning-by-doing approach, new techniques, strategies, arrangements and/or practices to improve (a) the closing of nutrient, water and urban waste cycles in urban and peri-urban agriculture; 
(b) short-chain delivery of food in urban and peri-urban areas; and (c) the multifunctional use of land in urban and peri-urban areas.

For that purpose, SUPURBFOOD's methodology was inspired by the integrated sustainability assessment approach, which is 'a cyclical, participatory process of scoping, envisioning, experimenting, and learning through which a shared interpretation of sustainability for a specific context is developed and applied in an integrated manner, in order to explore solutions to persistent problems of unsustainable development' [76] (p. 284). This cyclical, participatory process was interdisciplinary and involved non-linear knowledge generation and social learning [77]. It also implied that SUPURBFOOD and its research activities were not guided by or grounded in a well-delineated research question and design beforehand, but that specific research questions emerged during the course of the project.

The selection of the case study resulted from interviews with a diverse group of respondents (Table 1) and a regional focus group meeting on best practices for closing cycles [78] that were held in an early stage of the SUPURBFOOD project. The opinions and perspectives of this wider range of actors improved our understanding of the dynamics within the case study area. The actors we consulted were from different realms of society, and included practitioners, small-scale entrepreneurs, representatives of the local administration, and NGOs. The review and analysis of secondary data, including internal reports, official documents, legislation, project proposals, annual reports and statistical sources, complemented our understanding of the dynamics on closing cycles in the city region [72]. We further developed our knowledge by participating in stakeholder meetings, engaging in informal conversations, checking relevant websites and following the local newspapers. The storyline of the case study on biogenic waste recycling was informed by the lessons learnt from two regional focus group meetings and two international seminars organized around the theme of closing nutrient and water cycles [78-81] that were held as part of the SUPURBFOOD research project. These meetings formed part of the cyclical and participatory process of scoping, envisioning, experimenting and learning, and provided us with important insights on how to develop our research, both conceptually and methodologically. Finally, the storyline has been enriched from discussions with stakeholders that occurred in a series of small-scale seminars organized by La Red Revolta (an interdisciplinary research network of economists, agrarian historians, and forestry engineers).

Table 1. Categories of actors and number of interviews in the Vigo city region.

\begin{tabular}{lc}
\hline \multicolumn{1}{c}{ Role of Actors } & Number of Interviews \\
\hline Comuneiros (commoners) & 7 \\
Food shop entrepreneurs & 2 \\
Consumer group coordinators & 1 \\
Horticulturists with home delivery & 4 \\
Vegetable nursery entrepreneur & 1 \\
Compost producer & 1 \\
Forest technician & 1 \\
Coordinator market local food products & 1 \\
Representative of local administration & 1 \\
Alderman & 3 \\
Mayor & 1 \\
Activists/consumers & 2 \\
\hline
\end{tabular}

The story on the case itself has been developed by bringing together and triangulating data [82] collected through various methods: interviews, participant observation, regional and international workshops organized in the context of SUPURBFOOD, desk studies, and feedback from stakeholders on our preliminary research findings. These materials were subjected to selected coding, which helped to develop the storyline and to tease out and better understand the social dimensions of this example of circular economy. The main part of the field research was carried out between 2013 and 2015, and adopted a qualitative, micro-sociological, approach, involving in-depth interviews with key 
actors in the Val Miñor area. These focused specifically on the waste recycling project, and included the president of ORGACCMM (who refers to this platform of commoners' associations as the 'Asociación Galega'), members of the steering boards of the commoners' associations in the study area, the former project leader of the Val Miñor's biomass plant, and Abonos Lourido [83], an eco-innovative enterprise that runs a privately owned green waste composting project. The interviews were recorded, transcribed and then coded and analyzed. To a large extent, the process of initiating the biomass plant is the story of the commoners. In the SUPURBFOOD project we collaborated with these commoners, and although we have positioned their story in a wider conceptual framework, we find it important to tell their story by letting them 'speak' (through quotes from interviews) and (partly) interpret the dynamics in the case study. Their quotes, except those from the president of ORGACCMM, are anonymized, as some of them contain contested and politically sensitive opinions about land-use. These key actors were consulted throughout the SUPURBFOOD project, and some of them were revisited and interviewed again whilst drafting this paper.

The following section presents the story on the Mancomunidade Val Miñor case to design a biomass plant, to operate it on an experimental base and, how this initiative was ultimately frustrated and never became fully functional. Yet despite being a failure, this storyline illustrates the flows/cycles of ideas and practices that characterize the mechanisms entailed in the socially innovative practices of commoning and developing closed cycles.

\section{The Story of the Mancomunidade Val Miñor's Attempt to Construct a Bio-Composting Plant}

The story of the Val Miñor biomass project has several related aspects. The first relates to the aims and organizational form of local residents in terms of managing land use (Section 4.1), a second zooms in on their objective of improving the management of solid organic waste (Section 4.2), a third on the (frustrated and failed) development of a composting plant (Section 4.3), and the last on the aspirations to integrate the upcycling of forestry biomass and urban green waste so as to close cycles in the food chain (Section 4.4). The story provides a link between two activities, land management and waste management, which would generally be treated as separate, isolated sectoral concerns and it shows the need for municipal and regional governments to constructively engage with (or at least not obstruct) such innovative bottom-up approaches.

\subsection{The Management of the Commons}

As elsewhere in Galicia, the common land in the city region of Vigo is mostly used for wood production. In recent years there has been a move towards the reintroduction/rejuvenation of native species in order to enhance ecological services (water retention, fire prevention, biodiversity) and multifunctionality (forest fruit production, small-scale animal husbandry, etc.). The Mancomunidade Val Miñor sought to take this one step further by trying to develop a socially-innovative, bottom-up, approach to revalorizing the commons through closing nutrient cycles in order to enhance the sustainability of forestry management and the multifunctionality of the monte. The president of the ORGACCMM, who is also an active comuneiro and president of one of the Associations of the Commons in the Val Miñor area, is also involved in various other institutions, giving him insights into how governance operates at different levels. He explains why communal ownership and management of the monte is important:

'Our philosophy, and what we aim to demonstrate, is that the monte is multifunctional, and that it is the comuneiros who have to decide on how to use it. In this organization we provide information and train others, we bring people and ideas together, but nobody is obliged to follow up a proposal. We can make proposals, have ideas, but it is the Comunidade [the local dwellers organized in an Association of the Commons] that has to decide.'

Several mechanisms and procedures have been put in place to ensure the active participation of the members in decision-making and to prevent a small group of members deciding what happens: 
'It is a democratic system. At least $50 \%$ of the membership need to support a proposal at 'la primera convocatoria' (the first meeting) and $25-30 \%$ in any subsequent meetings. This means that a small group of, say, 5 people cannot manage the monte but that decisions must be quorate. More importantly, there is the right to revocation, which means that if people consider that things are being managed badly they can call for a new meeting. That [opportunity] does not exist at the level of the municipality, nor at the level of the Xunta [the regional government in Galicia] nor at the level of the nation state.'

However, the president of the ORGACCMM is also of the opinion that members could be more actively engaged and committed than is currently happening:

'People are not as engaged and participative as they could be. To my mind we talk more within the Xunta rectora [the board of his Association of the Commons] than [the comuneiros in] the assemblea [a meeting of all the comuneiros]. This is a weak point in many places. It is not the case with the Asociación Galega [ORGACCMM, one of the platforms of Associations of the Commons in Galicia], where we do debate things, since all the members of the Asociacion Galega are members of the Xuntas rectoras.'

In short, the management of the commons requires well-functioning governance mechanisms, including at the local level, although not all of these currently work as well as they could.

\subsection{Upcycling Solid Organic Waste in Val Miñor}

The project that the project in the Val Miñor area (Figure 1) tried to establish was a decentralized, small-scale organic composting operation which, although it did not directly involve municipalities or farmers, could have been attractive (and provided economic benefits) for both groups. Its core aim was to reduce fire risks in the monte and by doing so it would have closed nutrient cycles at the local level, by better maintaining the forests in the area and combining this 'waste' with urban green waste from municipalities (from the maintenance of parks, pruning of roadside trees, etc.), horticulturists, and tree nursery enterprises. The initial aim was to make a high-quality compost that would also have included Sacchoriza polyschides (a seaweed from which the sand and salt need to be removed before processing) and horse manure. In the initial design stage, it was decided to exclude domestic waste, due to the risk of contamination from non-organic materials.

To get the project started the Mancomunidade Val Miñor had to interact with several institutions: the land registry (to obtain permission for changes in land use and to construct physical infrastructure on the common land), the municipality (in order to access municipal green waste), and the Xunta de Galicia (the regional government, which was planning projects in the area-a wind park and mining activities-that would compete/conflict with the proposal).

\subsection{Building an Actor-Network}

The planning of the biomass plant for composting biogenic waste started at the end of the 1990s, when the Mancomunidade Val Miñor became interested in recycling green waste materials from the monte. The main motivations were to reduce the risk of forest fires, improve the management of communal woodlands, reduce scrub pressure, encourage the development of more mature trees; and improve the aesthetics and recreational opportunities of the common land. Compost production would modernize the traditional use of the monte in supporting agricultural production, both directly (the compost could be used to improve soil fertility on local smallholdings and/or in the monte area) and indirectly (the revenues derived from sales of the compost sales to others could finance improvement works on the common land).

Figure 2 shows the actors involved in this initiative, and identifies the events and conditions required for the initiative to flourish. The figure illustrates the project's long-term perspective, the required actor network, and the initiative's (past and present) institutional contexts. 


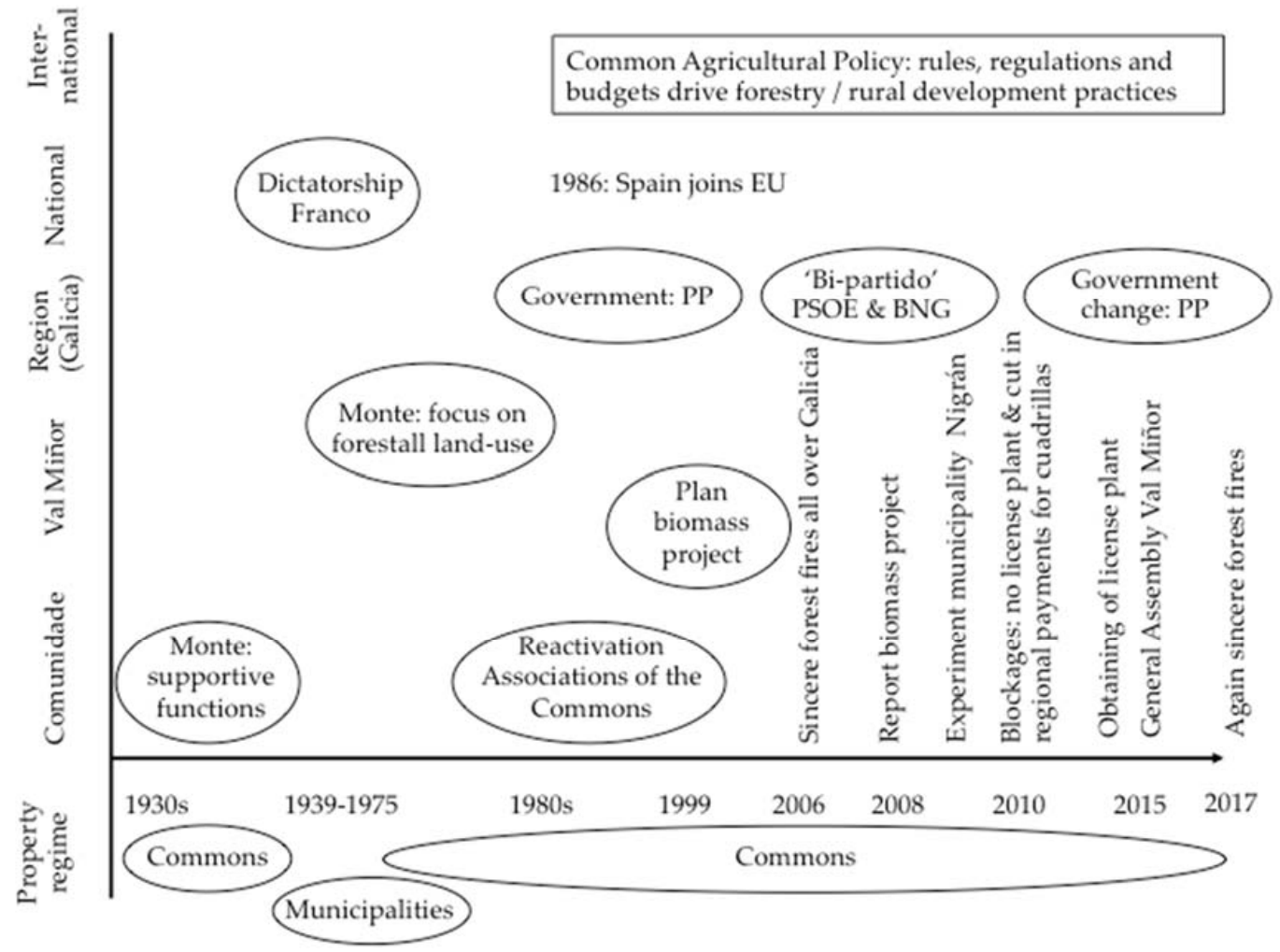

Figure 2. Land-use functions, scale of Val Miñor initiative, and governmental context over time; Partido Socialista Obrero Español (PSOE), Bloque Nacionalista Galego (BNG) and Partido Popular (PP).

In 1999, the Mancomunidade Val Miñor contacted the Asociación para la Economía Social (the Association for the Social Economy, a national non-profit platform on recycling) to discuss carrying out a viability study in biomass composting. The ORGACCMM president speaks of the association's aims at this time:

'The value added from the composting plant would benefit the Comunidades de Monte [the Associations of the Commons] and local residents. It would help us to create a living countryside, with the people who live in and from the countryside.'

Working groups were organized and, later in the same year, a team of two forestry engineers and an economist wrote an initial report, setting out the general objectives for the project and its technical and financial requirements. This was accompanied by a land management plan for renewing vegetal cover, cutting brush back into pasture, harvesting and composting the emergent bushes and scrub, and using this compost as a fertilizer for the pastures. This integrated rotation system had to take into account slope features, wind exposure and the sensitivity of areas to forest fires, and had a strong focus on reestablishing the traditional land multifunctional use in the monte area. The president of one of the commoners' associations explains:

'Converting eucalyptus plantations into pastures is not easy because the revenues will be reduced to zero, but we will achieve other goals. The comuneiros understood its relevance and took the decisions to change land-use patterns in our area as they recognized the value of having cattle graze in the area once again.'

The new land management regime, the transportation of materials to the composting plant, and the processing of these materials would result in seasonal employment. At the same time, the clearing of biomass would reduce the risk of forest fires, lessen fire damage, make fires easier to control and reduce their detrimental impact on the natural and aesthetic values of the area. 
The revenues from the compost plant would allow the communeiros to employ cuadrillas, teams of workers to clear and maintain the monte area. The foresight of the communeiros in trying to preempt this problem was amply demonstrated in 2017 when heavy fires in the Vincios area were responsible for the deaths of two local residents who were trapped by a forest fire. In the initial plan, these cuadrillas were to be financed by the regional government, which until 2009 had a budget to pay for this service. The combination of the financial crisis in 2009 and a newly-elected regional government led to this budget being cut and funds only being available for stopping, as opposed to preventing, forest fires. The same spokesman said:

'The biomass project started with the support of the [regional] government. There were the Partido Socialista Obrero Español (PSOE) and the Bloque (Bloque Nacionalista Galego, a regionalist left-wing party). When the Partido Popular (PP) took over it was all dismantled and we were left without anything. They broke the link between upcycling biomass and the teams of workers in the forest. They disassembled all the Mancomunidades, which can no longer receive subsidies to hire workers.'

At this time, this was very much a 'blue-sky' project as there were very few real-life experiences of such projects. It was necessary to bring together a wide range of stakeholders to explore the possibilities for implementing biomass production. These included researchers, pharmacists, biologists, forestry engineers, rangers and other professionals and people linked to the monte, agricultural production, and environmental challenges. Visits were made to similar initiatives in order to identify potential problems and benefits. One of the members of this ad hoc actor network was Abonos Lourido, an ecologically innovative private enterprise engaged in harvesting and processing Toxo (Ullex europaeus) from the monte, which had designed and built its own machinery to harvest and collect this vegetation which is processed into compost. The composting process (again developed by the company) takes about a year and the resulting compost is either reapplied to the monte, to improve its productive potential, or sold to professional vegetable and flower producers or hobby gardeners. The Mancomunidade Val Miñor was pursuing a similar business model. A president of one of the Associations of the Commons, spoke about the plans and the benefits they would bring:

'The idea was to separate the compost into the larger and smaller elements. Our aim was two-fold. First, to promote local employment, and allow the Comunidades de Montes to employ their own teams of workers in the monte. Second: to financially 'close the loop' of the work we were doing in the monte. Instead of paying to get rid of the biomass that we were clearing, we wanted to convert it into compost, and use this to improve the degraded parts of the monte, parts lacking organic material or sell to finance the management of the monte.'

The 2008 technical report estimated that the participating associations could generate 1877 tons of green organic matter from their communal forests, which would be supplemented by an additional 2439 tons of biogenic matter from public spaces in the Val Miñor area and generate almost 900 tons of compost per year. The biomass plant itself was planned to be built on a plot of land belonging to the Association of the Commons of Vincios (in the municipality of Gondomar), one of the members of the Mancomunidade Val Miñor, but problems with the planning procedures led to the permit for the biomass plant being delayed with another four years until spring 2014.

At this point the Mancomunidade Val Miñor had already gone ahead and purchased the machinery (tractors and other equipment to clear the forest) that it needed, and so rather than see it remain idle, decided to start composting experimentally in situ, in small-scale operations scattered over the 3553 hectares of land of the Mancomunidade Val Miñor.

\subsection{Creating a Value Chain}

Figure 3 is a schematic representation of the planned physical and economic flows for the Val Miñor composting project that emerged from the empirical evidence collected and analyzed within 
the SUPURBFOOD project, which was involved in helping the local community develop its plans to close the nutrient loop within and beyond the monte area. The original flow chart was drawn up in 2015 by Alfredo López, the secretary of the Mancomuniade Val Miñor, who was at the time the project leader for the biomass plant. Figure 3 builds upon that visualization and shows the links between different social actors (including citizens, enterprises, municipalities, the Association of the Commons, the EU Common Agricultural Policy and how it is applied nationally) and ways of closing the waste management cycle (that draws together a range of, seemingly disparate, 'sectoral' interests such as job creation, improving soil fertility and reducing the risk of forest fires). The dotted lines in the figure indicate unrealized (or poorly developed) connections.

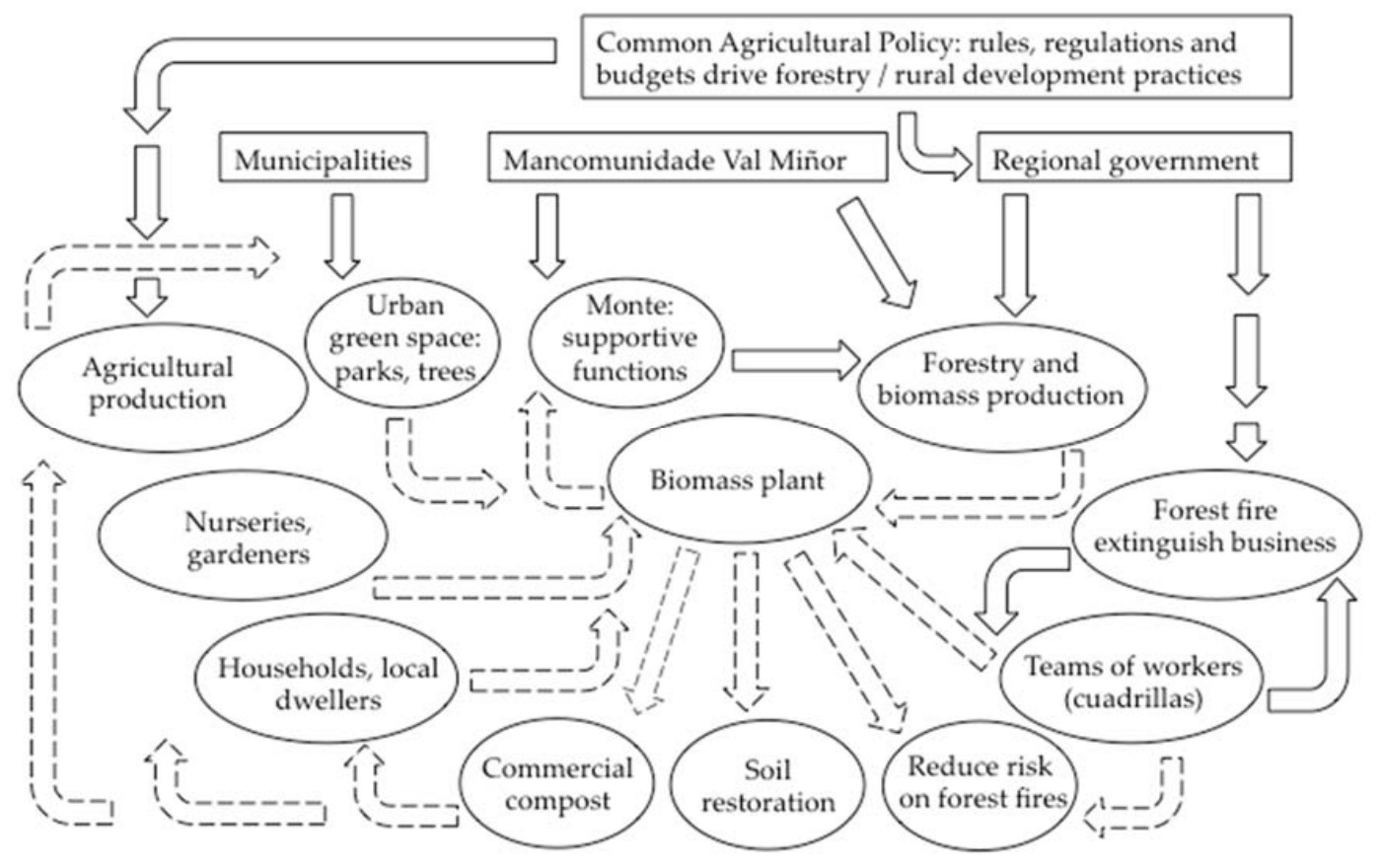

Figure 3. Schematic representation of the (sometimes absent) physical and economic flows for the Val Miñor biomass plant in a wider governance context. (Dotted lines represent 'unrealized' connections).

The Mancomuniade Val Miñor developed a new plan, which included collecting green waste derived from the maintenance of public green spaces in municipalities in Val Miñor, and green waste generated by individual households. While (as with green municipal waste.) there was a risk of contamination from plastics and metals, this was felt to be outweighed by the contribution it would make to completing the closure of nutrient loops, and its role in raising awareness (and 'ownership') among local citizens. However, the inclusion of household green waste put the proposal into conflict with a contract that a large private enterprise had already agreed to take in green waste from all over Galicia. The president of one of the Associations of the Commons recalls the conflicts that this gave rise to:

'They want biomass to burn and produce energy and to ensure that all of Galicia's biomass goes to their energy plants. If they had given us permission to start a competing project that conflicted with this then it would have set a precedent and they would not have been able stop others from taking a similar initiative. They didn't want this type of project to succeed as it would potentially divert biomass from their project. In Val Miñor there are about 3000 hectares that can supply biomass to make compost, which is also of use to them to produce energy.' 
In March 2015, about 15 years after the first ideas for the biomass plant were launched, the Mancomunidade Val Miñor felt obliged to revisit its initial plans and discussed the possibilities at its annual assembly. The possibilities discussed included expanding the initial business model to make the biomass plant a collection point for private and municipal green waste, and looking for external finance to pay the forest brigades to maintain the monte area. It was anticipated that the project would require 4 people working at the plant itself and another 20 to clean the 3000 hectares of monte that would supply it. These new ideas in part were influenced by a recognition, inspired by the experience of the SUPURBFOOD project, that the choice of scale would influence social acceptance and help to raise awareness about the value of green waste recycling. Initially, in 2008, all three municipalities in Val Miñor-Baiona, Nigrán, and Gondomar-were interested in collaborating (and the Mancomunidade had signed a contract with the municipality of Nigrán to supply it with crushed organic waste). Yet, there was a mismatch of expectations: while the project's projections anticipated that the municipalities participating in the project would reduce their costs, they expected their costs to increase and were reluctant to participate because of this. The project's collaboration with the three municipalities in Val Miñor, which had been sporadic and ad hoc, finally disintegrated, frustrated the implementation of the plant. The president of the Association of the Commons where the plant is located talks about the disappointment:

'We initiated the project under a lot of illusions and made large economic investments. The moment that the government had to take the initiative and help bring the project forward we were left completely high and dry. The project turned into a political football. The people in charge of dealing with it had no idea what it was all about at the local level.'

Without political support and supportive governance frameworks (from both the regional and municipal authorities) it proved impossible to make the project viable, especially since very few of the participating Associations of the Commons had the means to pay the teams of workers to gather, transport and process the materials. The same spokesman continues:

'When the cuadrillas still existed, we didn't have permission for the plant and weren't producing biomass. When the cuadrillas were disbanded we could no longer create the connection between working in the forest and producing biomass, so the plant lost its impetus. [ ... ] We already had the machines and, in 2015, wanted to push the project forward, and one of the possibilities was for all the member associations to put in the money to hire the workers. We needed people to transport the biomass from the forest to the plant, crush it, all that type of work [ ... ]. The costs of maintaining the plant in combination with the costs for the employing the cuadrillas was too much for the comunidades by themselves.'

As a fall back option, it was agreed that the associations would crush vegetation and branches from the pruning process in their own areas, and bring this to the biomass plant. Yet in 2015-2016 only three commons' associations undertook this work and, as a result, there was insufficient material for the plant to be economically viable.

\section{Discussion and Conclusions}

Circular economy thinking highlights the restorative and regenerative potential of closing cycles, reducing and minimizing waste and creating new value streams [84]. The case study of the Mancomunidade Val Miñor does provide us with a useful model of the metabolism of biogenic waste flows and cycles [4] and, although finally not successful, it does have a value in helping us understand how waste flows within a city region could be better connected. Furthermore, the link made between the management of the commons and circular economy provides valuable lessons for designing, developing and implementing socially innovative and inclusive approaches to circular economies. Val Miñor's design is a shining example of circular economy, as it not only redirects urban green waste back into the food production cycle, but also removes an environmental hazard 
(brushwood that can be the cause of forest fires) and turns it into a useful resource. The case study shows how the management of biogenic waste streams can help to improve the quality of the natural environment by reactivating and sustaining its supportive functions, whilst at the same time giving local communities more control over, and benefits from, material flows and cycles. Its novelty consists in the use of a socially inclusive perspective that provides both an empirical and conceptual example of good practice in circular economy thinking.

With the aim of furthering our understanding of the social sustainability pillar of the circular economy [2], we draw several lessons from this case study about this pillar, in particular regarding social innovation and socially inclusive development. Based on our analysis of the empirical findings we conclude that four social dimensions are key to commoning the circular economy: awareness-raising, collaborative management and decision-making, the equitable sharing of benefits among local residents, and a supportive institutional environment.

\subsection{Awareness-Raising}

Although the case study cannot be presented as a success story, the activities of the comuneiros have helped to raise awareness that their approach of commoning the circular economy holds the potential to manage and reduce the risk of forest fires, close waste cycles, generate jobs and produce an end product (compost) that could be sold and serve as input for the local food system, or used to restore the productivity of the monte. In 2008 the comuneiros developed a detailed plan for this [75], and started composting biogenic waste from locally available biomass, i.e., the up-cycling of solid organic waste into compost, which ranks highly in the waste hierarchy in the 2008/98/EC EU Directive [17]. Obviously, there are several other levels in the waste hierarchy where biogenic waste can be tackled, (e.g., fermenting instead of recycling). However, for green waste derived from better management of the monte, the maintenance of municipal open spaces and the activities of horticultural nurseries in a system in which the local community keeps control and benefits from the closure of loops, this project appears to intervene at the most appropriate level.

In this way, the case study provides design principles for a business model that develops synergies between cities, agriculture and forestry, which are currently lacking. In this respect, this initiative is a promising example of bottom-up social innovation, the process through which citizens learn how to use resources more sustainably, and which carries the potential to reduce the tensions between the social, ecological and economic pillars of sustainability. Awareness of the benefits that could accrue to local communities could encourage citizens and small-scale enterprises to get involved in closing loops at lower levels of aggregation.

\subsection{Collaborative Management and Decision-Making}

The attempts of the comuneiros in Val Miñor to establish efficient and sustainable biogenic waste management were rooted in existing social practices, structures and historical precedents on commoning [64,66,71]. In the case of the Val Miñor initiative, active comuneiros explained and defended the rationale for a different way of governing the circular economy. Commoning is formally recognized by Spanish legislation, and enables local communities to search and implement multifunctional land-use functions tailored to local conditions $[85,86]$. As with many other initiatives that present themselves (or are perceived) as alternatives to mainstream practices, Val Miñor faced many challenges in acquiring societal acceptance. These included the choice of organization and the scale of the initiative. Comuneiros in the case study stressed that its decentralized character holds the potential to favor social innovation. In this respect, the case study provides insights into how new organizational forms can help to raise awareness and change attitudes, perceptions and practices.

Although the case study 'failed', it can act as an inspiration in showing the potential of commoning for boosting community prosperity and resilience. In order for initiatives such as this case study to succeed in connecting flows and closing cycles, a certain 'experimental' space, or room for maneuver, is required [40]. This experimental space is on the one hand created through collaborative management 
and decision-making, but on the other hand it requires support from other, i.e., municipal, regional, and (supra-)national governance levels. We will come back to the latter in Section 5.4.

\subsection{Equitable Sharing of Benefits}

By commoning waste management, local communities can (potentially) benefit in multiple ways. Composting is practical and relatively cheap to implement, is locally grounded, provides opportunities for citizens to be involved, for awareness raising and generating socio-economic and ecological benefits for local communities $[87,88]$. All recycling systems require citizens to change their attitudes and practices. In a decentralized system, this may be easier to achieve as those involved will benefit, directly and/or indirectly, from making such behavioral changes.

The Val Miñor case is a clear example of the potential of decentralized waste management, which can create synergies between socio-economic and ecological benefits that accrue to the local community. Further evidence about strengthening beneficial relations between cities, agriculture, and forestry could be provided if the new plan was supported by a new analysis of the technical potentials and economic viability of the biomass plant (area, biomass available, interested partners, financial aspects). Such a study should cover the market opportunities for compost sales in the city region, and be linked to strategies for closing loops in other sectors, such as dairy farming.

\subsection{Supportive Institutional Environment}

The lack of political will on the part of the regional and municipal governments and opposition from outside forces contributed to the failure of a promising experiment of commoning-based waste management. The waste management solutions that were preferred by the regional administration involved adopting an approach at a lower level in the waste hierarchy: combustion, using waste to produce heat and/or electricity and combustion residues which can be contrasted to the solution provided by the Val Miñor design, for composting (using waste as raw material or substrate to produce compost that can then be used as a fertilizer in food production), which occupies a higher level in the waste hierarchy.

Although the comuneiros, as primary stakeholders, own and manage the largest part of the resource base which would have provided the inputs for compost production, their plans were also dependent on rules and regulations controlled by other institutions, that had alternative, conflicting policies or land-use plans $[69,89,90]$. These included plans for centralized biomass combustion that are reliant on securing access to domestic and municipal biogenic waste and the produce from extensive industrial-scale forestry monocultures [91]. In other cases policy regulations are obstructive towards the commoners, one example being the regulation that prevents Associations of the Commons from owning or developing wind parks and requires these to be privately owned [92,93]. Yet the comuneiros' innovative and viable approach to closing nutrient loops was frustrated by administrative and legal obstacles, delays in permission to build the plant, and the loss of the finance needed to pay the teams of workers. As such, the case study highlights a disconnection between the potential for strengthening the process of commoning, which would benefit local residents, and the rules, regulations and bureaucratic procedures of national and regional administrations. These governance levels are clearly more geared to dealing with waste management at a higher, more centralized level, and imply being locked into an approach that sits at a lower level in the waste hierarchy.

The comuneiros' attempt to close nutrient loops raises questions and issues about wider societal structures (both policies and markets) and the question of power in waste management: who owns waste? Who is entitled to make a business out of it? And who sets the criteria for deciding the type and scale of operations and the operators? Until now, research has largely focused on the role of the private sector and/or the state, thereby neglecting or ignoring the potential of the commons. It seems unlikely, given current priorities for using waste biomass to generate power and the economic constraints that local and regional governments face, that that this initiative will ever be realized. 


\subsection{By Way of Conclusion}

Despite the 'failure' of this initiative, our case study does address the gap in circular economy research and literature as identified by Murray et al. [2], i.e., lack of attention to the social dimensions of the circular economy. Morover, until now research has focused largely on the role of the private sector and/or the state, thereby neglecting or ignoring the potential of other ways of organizing and managing the circular economy. As our paper highlights, organizational forms such as the Mancomunidade Val Miñor provide an opportunity for closing nutrient loops through commoning, and can provide a basis for the transition towards a more circular, regenerative food system. The initiative shows the potential to create positive feedback loops and to close cycles at little or no cost to local and/or regional governments. The existence of viable, forward-thinking, organizational entities capable of managing the commons, holds the potential for developing a more socially-inclusive circular economy. However, in this case, this potential was thwarted by existing structures and established interests, in other words by a lack of a supportive institutional environment.

Author Contributions: P.S., M.D.D.G. and J.S.C.W. contributed to the conception and design; P.S. and M.D.D.G were involved in acquiring the field data; P.S., M.D.D.G and J.S.W. were involved in data analysis and interpretation. P.S. drew up the original draft paper with M.D.D.G and J.S.C.W making significant intellectual input.

Funding: The research for this article was carried as part of the 'SUPURBFOOD' project, which received funding from the European Union's Seventh Framework Programme for research, technological development and demonstration (grant agreement no 312126). The Xunta de Galicia provided financial support for the postdoctoral project 'POS-B/2016/028' which covered the costs of writing this article, publishing it in an open access format, and for language editing.

Acknowledgments: Our special thanks go those who commented on earlier versions of this article, and to the anonymous reviewers for their useful suggestions on how to improve this. Many thanks go to Nicholas Parrott (TextualHealing.eu) for providing English language editing and editorial advice. The responsibility for the views and the argumentation provided in this article lie with the authors.

Conflicts of Interest: The authors declare no conflict of interest.

\section{References}

1. Geissdoerfer, M.; Savaget, P.; Bocken, N.M.P.; Hultink, E.J. The circular economy-A new sustainability paradigm? J. Clean. Prod. 2017, 143, 757-768. [CrossRef]

2. Murray, A.; Skene, K.; Haynes, K. The circular economy: An interdisciplinary exploration of the concept and application in a global context. J. Bus. Ethics 2017, 140, 369-380. [CrossRef]

3. Reed, B. Shifting from 'sustainability' to regeneration. Build. Res. Inf. 2007, 35, 674-680. [CrossRef]

4. Agudelo-Vera, C.M.; Leduc, W.R.; Mels, A.R.; Rijnaarts, H.H. Harvesting urban resources towards more resilient cities. Resour. Conserv. Recycl. 2012, 64, 3-12. [CrossRef]

5. McDonough, W. Cradle to Cradle: Remaking the Way We Make Things; North Point Press: New York, NY, USA, 2002.

6. Braungart, M.; McDonough, W.; Bollinger, A. Cradle-to-cradle design: Creating healthy emissions-A strategy for eco-effective product and system design. J. Clean. Prod. 2007, 15, 1337-1348. [CrossRef]

7. De Zeeuw, H.; Drechsel, P. Cities and Agriculture. Developing Resilient Urban Food Systems; Earthscan: London, UK, 2015.

8. Hebinck, A.; Vervoort, J.M.; Hebinck, P.; Rutting, L.; Galli, F. Imagining transformative futures: Participatory foresight for food system change. Ecol. Soc. 2018, 23, 16. [CrossRef]

9. Wiskerke, J.S.C. On places lost and places regained: Reflections on the alternative food geography and sustainable regional development. Int. Plan. Stud. 2009, 14, 369-387. [CrossRef]

10. Wiskerke, J.S.C. Urban food systems. In Cities and Agriculture. Developing Resilient Urban Food Systems; de Zeeuw, H., Drechsel, P., Eds.; Earthscan: London, UK, 2015; pp. 1-25.

11. Bollier, D. Commoning as Transformative Social Paradigm. Esssay for the Next System Project; The Democracy Collaborative: Cleveland, OH, USA, 2016; Available online: https:/ / thenextsystem.org/sites/default/files / 2017-08/DavidBollier.pdf (accessed on 11 December 2017).

12. Marsden, T. Third natures? Reconstituting space through place-making strategies for sustainability. Int. J. Sociol. Agric. Food 2012, 19, 257-274. 
13. From Waste to Value: The Transition to a Circular Economy. Speech 22 May 2017. Available online: https: / / ec.europa.eu/commission/commissioners/2014-2019/vella/announcements/waste-value-transitioncircular-economy_en (accessed on 5 December 2017).

14. Wells, P.; Seitz, M. Business models and closed-loop supply chains: A typology. Supply Chain Manag. 2005, 10, 249-251. [CrossRef]

15. Guide, V.D.R., Jr.; Van Wassenhove, L.N. Or forum the evolution of closed-loop supply chain research. Oper. Res. 2009, 57, 10-18. [CrossRef]

16. Govindan, K.; Soleimani, H.; Kannan, D. Reverse logistics and closed-loop supply chain: A comprehensive review to explore the future. Eur. J. Oper. Res. 2015, 240, 603-626. [CrossRef]

17. Directive 2008/98/EC on Waste (Waste Framework Directive). Available online: http://ec.europa.eu/ environment/waste/framework/ (accessed on 6 January 2018).

18. MacArthur Foundation. Towards the Circular Economy: Economic and Business Rationale for an Accelerated Transition. Cowes, Ellen MacArthur Foundation, First Published 2012. Available online: https://www.ellenmacarthurfoundation.org/assets/downloads/publications/EllenMacArthur-Foundation-Towards-the-Circular-Economy-vol.1.pdf (accessed on 9 April 2018).

19. Schmid, O.; Dominguez Garcia, M.D.; Van der Schans, J.W.; Ge, L.; Guyer, C.; Fritschi, R.; Bachmann, S.; Swagemakers, P.; Simón Fernández, X.; López, A.; et al. Deliverable 4.4, Closing of Nutrient, Water and Urban Waste Cycles in Urban and Peri-Urban Agriculture. SUPURBFOOD Project, 2015. Available online: www.supurbfood.eu (accessed on 22 February 2018).

20. Renting, H.; Rossing, W.A.H.; Groot, J.C.J.; van der Ploeg, J.D.; Laurent, C.; Perraud, D.; Stobbelaar, D.J.; van Ittersum, M.K. Exploring multifunctional agriculture: A review of conceptual approaches and prospects for an integrative transitional framework. J. Environ. Manag. 2009, 90, 112-123. [CrossRef] [PubMed]

21. Swagemakers, P.; Dominguez Garcia, M.D.; Onafa Torres, A.; Oostindie, H.; Groot, J.C.J. A values-based approach to exploring synergies between livestock farming and landscape conservation in Galicia (Spain). Sustainability 2017, 9, 1987. [CrossRef]

22. Kraussmann, F.; Schandl, H.; Siferle, R.P. Socio-ecological regime transitions in Austria and the United Kingdom. Ecol. Econ. 2008, 65, 187-201. [CrossRef]

23. Duncan, J.; Pascucci, S. Circular solutions for linear problems: Principles for sustainable food futures. Solutions 2016, 7, 58-65. Available online: https:/ / www.thesolutionsjournal.com/article/circular-solutionslinear-problems-principles-sustainable-food-futures / (accessed on 8 December 2017).

24. Ostrom, E. Collective action and the evolution of social norms. J. Econ. Perspect. 2000, 14, 137-158. [CrossRef]

25. Ostrom, E. Beyond markets and states: Polycentric governance of complex economic systems. Am. Econ. Rev. 2010, 100, 641-672. [CrossRef]

26. Vivero-Pol, J.L. Food as commons or commodity? Exploring the links between normative valuations and agency in food transition. Sustainability 2017, 9, 442. [CrossRef]

27. Rundgren, G. Food: From commodity to commons. J. Agric. Environ. Ethics 2016, 29, 103-121. [CrossRef]

28. Dalla Costa, M.R. Food as common and community. Commoner 2007, 12, 129-137.

29. Quilligan, J.B. Why distinguish common gooos from public goods? In The Wealth of the Commons: A World Beyond Market and State; Bollier, D., Helfrich, S., Eds.; Levellers Press: Amherst, NY, USA, 2012; pp. $73-81$. Available online: http:/ / wealthofthecommons.org/essay/why-distinguish-common-goods-public-goods (accessed on 19 February 2018).

30. Hardin, G. The tradegy of the commons. Science 1968, 162, 1243-1248. [PubMed]

31. Linebaugh, P. The Magna Carta Manifesto. Liberties and Commons for All; University of California Press: Berkely, CA, USA, 2008.

32. Hensen, Z. Sustainable Community Systems: Commoning and Spatial Production. Theory Action 2016, 9 , 32-51. [CrossRef]

33. Ostrom, E. Crossing the great divide: Coproduction, synergy and development. World Dev. 1996, 24, 1073-1087. [CrossRef]

34. Wellbrock, W.; Roep, D.; Mahon, M.; Kairyte, E.; Nienaber, B.; Domínguez García, M.D.; Kriszan, M.; Farrell, M. Arranging public support to unfold collaborative modes of governance in rural areas. J. Rural Stud. 2013, 32, 420-429. [CrossRef]

35. Jongerden, J.; Swagemakers, P.; Barthel, S. Connective storylines: A relational approach to the design and management of urban green infrastructures. Span. J. Rural Dev. 2014, 5, 7-18. [CrossRef] 
36. Van Mierlo, B.; Leeuwis, C.; Smits, R.; Klein Woolthuis, R. Learning towards system innovation: Evaluating a systemic instrument. Technol. Forecast. Soc. Chang. 2010, 77, 318-334. [CrossRef]

37. Bock, B.B. Social innovation and sustainability; how to disentangle the buzzword and its application in the field of agriculture and rural development. Stud. Agric. Econ. 2012, 114, 57-63. [CrossRef]

38. Smith, A.; Vo $\beta$, J.P.; Grin, J. Innovation studies and sustainability transitions: The allure of the multi-level perspective and its challenges. Res. Policy 2010, 39, 435-448. [CrossRef]

39. Geels, F.W.; Schot, J. Typology of sociotechnical transition pathways. Res. Policy 2007, 36, 399-417. [CrossRef]

40. Wiskerke, J.S.C.; Bock, B.B.; Stuiver, M.; Renting, H. Environmental co-operatives as a new mode of rural governance. Neth. J. Agric. Sci. 2003, 51, 9-25. [CrossRef]

41. Reed, M.; Mettepenningen, E.; Swagemakers, P.; Dominguez Garcia, M.D.; Jahrl, I.; Koopmans, M.E. The challenges of governing urban food production across four European city-regions: Identity, sustainability and governance. Urban Agric. Reg. Food Syst. 2018, 3, 160006. [CrossRef]

42. Lamine, C. Settling shared uncertainties: Local partnerships between producers and consumers. Sociol. Rural. 2005, 45, 324-345. [CrossRef]

43. Moulaert, F.; Martinelli, F.; Swyngedouw, E.; Gonzalez, S. Towards alternative model(s) of local innovation. Urban Stud. 2005, 42, 1969-1990. [CrossRef]

44. Rip, A.; Kemp, R. Technological change. In Human Choice and Climate Change; Rayner, S., Malone, E.L., Eds.; Battelle Prêss: Colombus, OH, USA, 1998; Volume 2, pp. 327-399.

45. Neumeier, S. Why do do social innovations in rural development matter and should they be considered more seriously in rural development research? - Proposal for a stronger focus on social innovations in rural development research. Sociol. Rural. 2012, 52, 48-69. [CrossRef]

46. Shucksmith, M. Disintegrated rural development? Neo-endogenous rural development, planning and place-Shaping in diffused power contexts. Sociol. Rural. 2010, 50, 1-14. [CrossRef]

47. Fratesi, U.; Perucca, G. Territorial Capital and the Effectiveness of Cohesion Policies: An Assessment for CEE Regions. Investig. Reg. 2014, 29, 165-191.

48. Swagemakers, P.; Copena Rodríguez, D.; Domínguez García, M.D.; Simón Fernández, X. Fighting for a future: An actor-oriented planning approach to landscape preservation in Galicia. Dan. J. Geogr. 2014, 114, 109-118. [CrossRef]

49. Gibson-Graham, J.K. Diverse economies: Performative practices for 'other worlds'. Prog. Hum. Geogr. 2008, 1-20. [CrossRef]

50. Kemp, R.; Schot, J.; Hoogma, R. Regime shifts through processes of niche formation: The approach of strategic niche management. Technol. Anal. Strateg. Manag. 1998, 10, 175-196. [CrossRef]

51. Wilderer, P.; Schreff, D. Decentralized and centralized wastewater management: A challenge for technology developers. Water Sci. Technol. 2000, 41, 1-8. [CrossRef]

52. Tchobanoglous, G.; Leverenz, H. The rationale for decentralization of wastewater infrastructure. In Source Separation and Decentralization for Wastewater Management; Larsen, T.A., Udert, K.M., Lienert, J., Eds.; IWA Publishing: London, UK, 2013; pp. 101-116.

53. Brunori, G.; Galli, F. Sustainability of local and global food chains: Introduction to the special issue. Sustainability 2016, 8, 765. [CrossRef]

54. Marsden, T. Mobilizing the regional eco-economy: Evolving webs of agri-food and rural development in the UK. Camb. J. Reg. Econ. Soc. 2010, 3, 225-244. [CrossRef]

55. Berkes, F.; Folke, C. Linking Social and Ecological Systems for Resilience and Sustainability: Management Practices and Social Mechanisms for Building Resilience; Cambridge University Press: Cambridge, UK, 1998.

56. Folke, C. Resilience: The emergence of a perspective for social-ecological systems analyses. Glob. Environ. Chang. 2006, 16, 253-267. [CrossRef]

57. Oostindie, H. Unpacking Dutch multifunctional agrarian pathways as processes of peasantisation and agrarianisation. J. Rural Stud. 2017, in press. [CrossRef]

58. Runhaar, H.A.C.; Melman, T.C.P.; Boonstra, F.G.; Erisman, J.W.; Horlings, L.G.; De Snoo, G.R.; Termeer, C.J.A.M.; Wassen, M.J.; Westerink, J.; Arts, B.J.M. Promoting nature conservation by Dutch farmers: A governance perspective. Int. J. Agric. Sustain. 2017, 15, 264-281. [CrossRef]

59. Domínguez García, M.D.; Swagemakers, P.; Copena Rodríguez, D.; Covelo Alonso, J.; Simón Fernández, X. Collective agency and collaborative governance in managing the commons: The case of "A Serra do Galiñeiro" in Galicia, Spain. Span. J. Rural Dev. 2014, 5, 49-64. [CrossRef] 
60. Dominguez Garcia, M.D.; Simón Fernández, X.; Swagemakers, P. Edible landscape: Food and services from common-land use in the Vigo city region. Urban Agric. Mag. 2015, 29, 54-56.

61. Barthel, S.; Folke, C.; Colding, J. Social-Ecological Memory in Urban Gardens-Retaining the capacity for management of ecosystem services. Glob. Environ. Chang. 2010, 20, 255-265. [CrossRef]

62. Barthel, S.; Parker, J.; Ernstson, H. Food and green space in cities: A resilience lens on gardens and urban environmental movements. Urban Stud. 2015, 52, 1321-1338. [CrossRef]

63. Colding, J.; Barthel, S. The potential of 'Urban Green Commons' in the resilience building of cities. Ecol. Econ. 2013, 86, 156-166. [CrossRef]

64. Soto, D. Community, institutions and environment in conflicts over commons in Galicia, Northwest Spain (18th-20th centuries). Int. J. Strikes Soc. Confl. 2014, 5, 58-76.

65. Bouhier, A. La Galice. Essai Géographique D'analyse et D'interprétation d'un Vieux Complexe Agraire; Imprimerie Yonnaise: La-Roche-sur-Yon, France, 1979.

66. Soto, D. Conflicto ambiental, transformaciones productivas y cambio institucional. Los comunales de Galicia (España) durante la transición a la democracia. Hist. Ambient. Latinoam. Caribeña 2016, 6, 105-121.

67. Marey Pérez, M.F.; Crecente Maseda, R.; Rodríguez Vicente, V. Claves para comprender los usos del monte en Galicia (España) en el siglo XX. In Proceedings of the 2nd Latin American Symposium on Forest Management and Economics, Barcelona Spain, 18-20 September 2004.

68. Caballero, G. Community-based forest management institutions in the Galician communal forests: A new institutional approach. For. Policy Econ. 2015, 50, 347-356. [CrossRef]

69. Consulta CC 30/2017. Comité de Flora y Fauna Silvestres. Comité Científico del Ministerio de Agricultura, Pesca, Alimentación y Medio Ambiente. Available online: http:/ / praza.gal/xornal/uploads/dictamen_comite_ cientifcio_eucalyptus-dec2017.pdf (accessed on 6 April 2018).

70. Fernández Leiceaga, X.; Iglesias, E.L.; Rodríguez, M.J.; Rodríguez, B.B.; Outeiriño, P.V.; López, X.L.B.; Prieto, L.F.; Fernández, D.S. Os Montes Veciñais en Man Común: O Patrimonio Silente. Natureza, Economía, Identidade e Democracia na Galicia Rural; Edicioins Xerais de Galicia: Vigo, Spain, 2006.

71. Dominguez Garcia, M.D.; Soto, D. From an "integrated" to a "dismantled" landscape. In The Economic Value of Landscapes; Van der Heide, M., Van der Heijman, W., Eds.; Routledge: London, UK, 2012; pp. $204-223$.

72. Dominguez Garcia, M.D.; Copena, D.; Swagemakers, P.; Simón Fernández, X. The Metropolitan Area of Vigo in the Northwestern Part of Spain. Deliverable 2.2, Work Package 2. SUPURBFOOD Project. 2013. Available online: www.supurbfood.eu (accessed on 22 February 2018).

73. Kurtz, C. Working with Stories in Your Community or Organization. Participatory Narrative Inquiry; Kurtz-Fernhout Publishing: New York, NY, USA, 2009; Available online: http:/ / www.workingwithstories. org (accessed on 14 January 2016).

74. Vanclay, F. Guidance for the Design of Qualitative Study Evaluation; A Short Report to DG Regio; Department of Cultural Geography, University of Groningen: Groningen, The Netherlands, 2012.

75. López, A.; et al. Compostaxe: Prevención e Restauración. Informe Annual 2008 (Composting: Prevention and Restoration. Annual Report 2008); Organización Galega de Montes Veciñais en Man Común, Mancomunidade de Montes Veciñais en Man Común de Val Miñor, Universidade de Vigo: Vigo, Spain, 2008.

76. Weaver, P.; Rotmans, J. Integrated sustainability assessment: What is it, why do it and how? Int. J. Innov. Sustain. Dev. 2006, 1, 284-303. [CrossRef]

77. Rotmans, J. Tools for integrated sustainability assessment: A two-track approach. Integr. Assess. 2006, 6, 35-57.

78. Dominguez Garcia, M.D.; Swagemakers, P.; Simón Fernández, X. Deliverable 8.3, City-Region Workshops. Stakeholder Meetings in SUPURBFOOD's City-Regions. SUPURBFOOD Project, 2013. Available online: www.supurbfood.eu (accessed on 22 February 2018).

79. Dominguez Garcia, M.D.; Swagemakers, P.; Simón Fernández, X.; Koopmans, M.; Mettepenningen, E.; Van Huylenbroeck, G.; Kunda, I.; Tisenkopfs, T.; Grīviňš, M.; Reed, M.; et al. Deliverable 8.7, 2nd City-region Workshops Report. SUPURBFOOD Project, 2015. Available online: www.supurbfood.eu (accessed on 22 February 2018).

80. Swagemakers, P.; Hegger, E.; Wiskerke, J.S.C. Summary Report. In Proceedings of the SUPURBFOOD 1st International Seminar, Vigo, Spain, 26-27 June 2013; SUPURBFOOD Project, 2013. Available online: www.supurbfood.eu (accessed on 22 February 2018). 
81. Swagemakers, P.; Dubbeling, M.; Wiskerke, J.S.C. ICLEI Resilient Cities 2015. In Proceedings of the Urban Food Forum/Second SUPURBFOOD International Seminar, Bonn, Germany, 10 June 2015; SUPURBFOOD Project, 2015. Available online: www.supurbfood.eu (accessed on 22 February 2018).

82. Turner, S.F.; Cardinal, L.B.; Burton, R.M. Research design for mixed methods: A triangulation-based framework and roadmap. Organ. Res. Methods 2017, 20, 243-267. [CrossRef]

83. Abonos Lourido. Available online: http://abonoslourido.com/es/ (accessed on 9 April 2018).

84. What Is a Circular Economy? Ellen MacArthur Foundation, 2010. Available online: https://www. ellenmacarthurfoundation.org/circular-economy (accessed on 6 January 2018).

85. Sandstrom, E.; Ekman, A.K.; Lindholm, K.J. Commoning in the periphery-The role of the commons for understanding rural continuities and change. Int. J. Commons 2017, 11, 508-531. [CrossRef]

86. Lana, J.M.; Iriarte-Goñi, I. Commons and the legacy of the past. Regulation and uses of common lands in twentieth century Spain. Int. J. Commons 2015, 9, 510-532. [CrossRef]

87. Cofie, O.; Jackson, L. Deliverable 3.2, Thematic Paper 1: Innovative Experiences with the Reuse of Organic Wastes and Wastewater in (peri-) Urban Agriculture in the Global South. SUPURBFOOD Project, 2013. Available online: http:/ / www.supurbfood.eu/scripts/document.php?id=71 (accessed on 7 January 2018).

88. Wiskerke, J.S.C.; Verhoeven, S. Flourishing Foodscapes: Socio-Spatial Design Principles for Regenerative City Region Food Systems; Valiz: Amsterdam, The Netherlands, 2018; in press.

89. Pérez Pena, M. O Comité Científico do Ministerio Resolve que o Eucalipto é Unha Especie Invasora e Recomenda a Súa Erradicación. Praza Pública, 2018. Available online: http:/ /praza.gal/movementos-sociais/16397/o-comitecientifico-do-ministerio-resolve-que-o-eucalipto-e-unha-especie-invasora-e-recomenda-a-sua-erradicacion/ (accessed on 6 April 2018).

90. Ansede, M. El Gobierno Rechaza Clasificar el Eucalipto Como Especie Invasora. El País, 2018. Available online: https:/ / elpais.com/elpais/2018/04/04/ciencia/1522857047_252833.html (accessed on 6 April 2018).

91. Copena, D.; Simón, X. La produccion de energia electrica a partir de la biomasa forestal primaria: Analisis del caso gallego. Revista Galega de Economía 2014, 23, 91-111.

92. Simón, X.; Copena, D. Eolic energy and rural development: An analysis for Galicia. Span. J. Rural Dev. 2012, 1, 13-28. [CrossRef]

93. Simón Fernández, X.; Copena Rodríguez, D. Enerxía Eólica en Galicia: O Seu Impacto no Medio Rural [Wind Energy in Galicia: Its Impact on the Countryside]; Universidade de Vigo, Servizo de Publicacións: Vigo, Spain, 2013. (In Galician)

(C) 2018 by the authors. Licensee MDPI, Basel, Switzerland. This article is an open access article distributed under the terms and conditions of the Creative Commons Attribution (CC BY) license (http:/ / creativecommons.org/licenses/by/4.0/). 